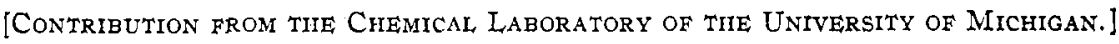

\title{
THE PREPARATION OF BENZYL ESTERS AND OTHER BENZYL- DERIVATIVES FROM BENZYL CHLORIDE.
}

By M. Gomberg and C. C. Buchler.

Received June 15, 1920.

The facility with which carbon tetrachloride, benzotrichloride and benzophenone chloride can be made to condense with various derivatives of the aromatic series, with the aid of catalysts and of ten without them, suggested the idea that benzyl chloride also might be brought into a wider number of direct combinations than has been done hitherto, diverse as the reactivity of benzyl chloride is already known to be. The susceptibility of benzyl chloride to various metals has been observed before. Marussia Bakunin succeeded in inducing condensation of benzyl chloride with phenol, ${ }^{1}$ and with $\alpha$ - and $\beta$-naphthol ${ }^{2}$ by the use of zinc as catalyst. Onufrowicz $z^{3}$ observed that benzyl chloride, heated with a considerable amount of copper at IIO-I $40^{\circ}$, gave dibenzyl; but, as hydrochloric acid is produced, the reaction must be more complicated than the author judged. In technical works it has been found necessary to employ distilling vessels with the interior glass-enameled, in order to avoid the catalytic influence of iron which may otherwise lead to explosive decomposition of the chloride.

A trial with phenol showed us that benzyl chloride begins to react with it at $160-80^{\circ}$, with evolution of hydrogen chloride. The addition, however, of a minute quantity of copper bronze was found to accelerate the

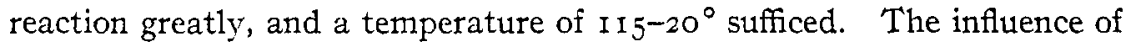
copper was next tested in the preparation of benzyl esters. Benzyl chloride was heated with dry sodium benzoate under a reflux condenser for from 6 to ro hours, but even in the most successful experiments the yield of the ester was only io to $18 \%$. However, on the addition of a small amount of copper powder, the yield rose to 50 or $60 \%$. This is probably the highest yield that may be expected in this reaction, for the reason that while copper undoubtedly accelerates the reaction between benzyl chloride and sodium benzoate, at the same time it accelerates the decomposition of the benzyl chloride itself. As a matter of fact, there was produced invariably a certain amount of a high-boiling viscous brown mass. A blank experiment with benzyl chloride and a very small amount of copper powder proved definitely that the above mentioned by-product results from the decomposition of some benzyl chloride.

Thus, the dry method, while fairly satisfactory, was found to have its

1 Bakunin Gazz. chim. ital., [2] 33, 454 (1903).

2 Bakunin and Barberio, ibid., 33, 457 (1903); Bakunin and Altieri, ibid., 33, 487 (1903).

Onufrowicz, Ber., I7, 833 (1884). 
limitations as regards the yield of ester. The addition to the mixture of benzyl benzoate as a solvent was without noticeable effect, since the amount of viscous by-product was about the same as before. Alcohol as a medium for this sort of reaction has been extensively used in the past. Obviously, for large scale production, water, if it could serve the purpose, would be preferable. Benzyl chloride, while generally quite reactive, is nonetheless remarkably stable towards water for such an active substance, and can even be distilled with steam. It owes its protection against rapid hydrolysis to the fact that it is only slightly soluble in water; this, at the same time, favors the reversibility of the reaction (I). Since this is the case, it seemed probable that benzyl chloride would give esters when it reacted with the salts of organic acids in aqueous solution, because the benzyl esters, as a rule, are even less soluble in water than is the chloride, and, consequently, worild suffer hydrolysis at a rate even slower than the chloride. Evidently the successful preparation of esters by this procedure is contingent upon the relative velocities of the 3 principal reactions.

$$
\begin{gathered}
\mathrm{C}_{6} \mathrm{H}_{5} \mathrm{CH}_{2} \mathrm{Cl}+\mathrm{H}_{2} \mathrm{O}=\mathrm{C}_{6} \mathrm{H}_{5} \mathrm{CH}_{2} \mathrm{OH}+\mathrm{HCl} \\
\mathrm{C}_{6} \mathrm{H}_{5} \mathrm{CH}_{2} \mathrm{Cl}+\mathrm{NaOCOR}=\mathrm{C}_{6} \mathrm{H}_{5} \mathrm{CH}_{2} \mathrm{OCOR}+\mathrm{NaCl} \\
\mathrm{C}_{6} \mathrm{H}_{5} \mathrm{CH}_{2} \mathrm{OCOR}+\mathrm{H}_{2} \mathrm{O}=\mathrm{C}_{6} \mathrm{H}_{5} \mathrm{CH}_{2} \mathrm{OH}+\mathrm{HOCOR}
\end{gathered}
$$

It should be feasible to determine by experiment in the case of each individual acid just what are the most favorable conditions as regards time and temperature of reaction in order to get the highest yield of ester according to this procedure.

Trials with sodium benzoate gave quite satisfactory results. Yields of the ester up to 70 or $80 \%$ of the calculated amount were readily obtained, and the only by-product found was benzyl alcohol. Catalysts were found to be without effect. By the same procedure good results were obtained with acetic, propionic, butyric, lactic, phenylacetic and cinnamic acids; fair results with salicylic and succinic acids; no ester, or but a small amount, was obtained with formic, oxalic and o-phthalic acids. We have not attempted at this time to determine the most favorable conditions for the preparation of each ester; our main aim has been to find out how generally applicable this method is. In view of its apparent simplicity, it is strange that the procedure here described should have failed of application in the past. We have found only one instance where it has been employed. Paal and Bodewig ${ }^{1}$ found that 0 -nitrobenzyl chloride, when heated with sodium acetate or benzoate in alcohol, gave only relatively small amounts of the ester, but in water good yields of the esters were obtained, and in each case the product was free from unchanged benzyl chloride.

Some additional experiments were made to determine to what extent

I Paal and Bodewig, Ber., 25, 2962 (1892). 
it may prove possible to employ aqueous solutions in the coupling of benzyl chloride with phenols, with ammonia or with amines, and in the preparation of benzyl cyanide and of benzyl alcohol. The results obtained indicate that such a procedure is quite feasible.

\section{Esters.}

Benzyl Benzoate.-Claisen' $\mathrm{s}^{1}$ method, an extension of the Cannizzaro reaction, has been the standard for the preparation of this ester. Benzaldehyde, heated at $100^{\circ}$ with a small amount of sodium benzylate, suffers intermolectlar condensation, and yields benzyl benzoate as the principal product.

$$
{ }_{2} \mathrm{C}_{6} \mathrm{H}_{5} \mathrm{CHO} \longrightarrow \mathrm{C}_{6} \mathrm{H}_{5} \mathrm{COOCH}_{2} \mathrm{C}_{6} \mathrm{H}_{5} \text {. }
$$

The substitution of aluminum alcoholate ${ }^{2}$ for sodium benzylate can hardly be considered as an essential modification. Other reactions recorded to give more or less ester are interesting from the theoretical point of view only.

The advantage of the Claisen method is that benzaldehyde, almost entirely free from chlorine in the nucleus, can be obtained on a technical scale fairly readily, certainly more readily than benzyl chloride; and such aldehyde, of course, would yield benzyl benzoate practically free from chlorine. The complaint that a great deal of the ester lately on the market contained considerable amounts of chlorine, suggests either that the ester has been made by the Claisen method from benzaldehyde not sufficiently free from chlorine-substituted aldehydes, or that, perhaps, it has been made through the interaction of benzyl chloride with sodium benzoate. If the latter surmise be correct, then the chlorine in the ester may have come either from an admixture in the reacting mass of some chloro-substituted benzyl chloride, or of some chloro-benzoic acid. If this, however, were the only source of chlorine in the reaction product, then there should be no great difficulty in separating benzyl benzoate from these higher boiling chloro-substituted esters through fractional distillation in vacuo. But the separation of benzyl benzoate from the last traces of benzyl chloride is not readily accomplished merely by distillation. There is good reason to believe that commercial benzyl benzoate, if it contains chlorine, owes its content of the latter not so much to the presence of chloro-substituted esters as to the presence of some benzyl chloride, assuming that the ester was made directly from benzyl chloride. A similar conclusion has been reached by Braisaz ${ }^{3}$ concerning the source of chlorine in benzyl acetate and other benzyl derivatives which are made directly from benzyl chloride.

${ }^{1}$ Claisen, Ber., 20, 646 (I887); Comp. Earl of Berkeley, J. Chem. Soc., I09, 522 (I9I0).

${ }^{2}$ Tischtschenko, J. Russ. Phys. Chem. Soc., 38, 355 (1906).

4.3raisaz, Mon. sci., 24, 384 (1.9! r ). 
We do not know whether benzyl benzoate actually has been made on a technical scale by the action of benzyl chloride on sodium benzoate. In our own laboratory experiments, the following procedure was adopted. Benzyl chloride was placed in a flask and $2 \mathrm{~g}$. in excess of the required amount of thoroughly dried sodium benzoate was added. Then the mixture, with or without the addition of the catalyst, was heated under a reflux condenser in a metal bath until no appreciable amounts of benzyl chloride reached the condenser. At this stage, water was added to the solid mass, the solution was made alkaline, and the ester was extracted witl benzene. After the solution was dried the solvent was distilled and the residue fractionated. At first some unchanged benzyl chloride ustally came over, then the temperature rose rapidly, and the fraction between $320-330^{\circ}$ was collected separately and was considered as practically pure ester, its boiling-point being $323^{\circ}$. Some dark-colored, heavy oil was always left in the distillation flask. This product resulted from the catalytic decomposition of benzyl chloride itself. The catalysts tried were copper bronze, of which in each experiment only a few mg. was used, and nickel, employed as nickel chloride. In each run $32 \mathrm{~g}$. of benzyl chloride was used, which required for complete reaction $36 \mathrm{~g}$. of sodium benzoate, while the amount actually employed was $38 \mathrm{~g}$. The acid which did not enter into the reaction was always recovered and its quantity determined; this served as a check upon the yields of the ester as actually found by distillation. The yield calculated as that theoretically possible was based upon the amount of the benzyl chloride employed. Table I gives a summary of the experiments. In Run No. 8, $30 \mathrm{~g}$. of benzyl benzoate was added to the reaction mixture at the beginning of the experiment, and this amount was subtracted from the ester recovered at the end of the experiment.

TABLE I.

38 G. of Sodium Benzoate and 32 G. of Benzyl Chloride Used in Each Experiment.

\begin{tabular}{|c|c|c|c|c|c|}
\hline \multirow{2}{*}{$\begin{array}{l}\text { Run } \\
\text { No. }\end{array}$} & \multirow{2}{*}{$\begin{array}{l}\text { Temp. of } \\
\text { metal bath. } \\
\text { o C. }\end{array}$} & \multirow{2}{*}{$\begin{array}{c}\text { Time } \\
\text { of rus. } \\
\text { Hrs. }\end{array}$} & \multirow[b]{2}{*}{ Catalyst. } & \multicolumn{2}{|c|}{ Yield of ester. } \\
\hline & & & & G. & $\%$. \\
\hline I... & $200-205$ & 6 & $\cdots$ & 7.0 & I 3.2 \\
\hline $2 .$. & $200-230$ & 6 & & 10.0 & 18.8 \\
\hline $3 .$. & Refluxed & I. 5 & $\mathrm{Cu}$ & 8.0 & II. 3 \\
\hline $4 .$. & $190-205$ & $3 \cdot 5$ & $\mathrm{Cu}$ & 29.5 & 55.6 \\
\hline 5. & $190-205$ & 6 & $\mathrm{Cu}$ & 24.0 & $45 \div 2$ \\
\hline 6. & $200-240$ & 6 & $\mathrm{Cu}$ & 28.0 & 52.8 \\
\hline 7. & $235-260$ & 6 & $\mathrm{Cu}$ & 28.0 & 52.8 \\
\hline $8^{a}$. & $250-260$ & 6 & $\mathrm{Cu}$ & 30.0 & 56.6 \\
\hline $9 \ldots$ & $190-300$ & $3 \cdot 5$ & $\mathrm{Cu}$ & 32.0 & 60.3 \\
\hline IO... & $200-300$ & 6 & $\mathrm{Cu}$ & 32.0 & 60.0 \\
\hline II ... & $200-210$ & 5 & $\mathrm{NiCl}_{2}$ & 14.0 & 26.4 \\
\hline
\end{tabular}

Thus, with the aid of copper as catalyst, yields of 50 to $60 \%$ of the ester 
may be obtained by this procedure. The ester, however, contains some benzyl chloride, which can be removed only by subsequent treatment of the ester with dil. alkali. Also, it contains a small amount of the highboiling product which results from the decomposition of benzyl chloride, which accounts for the fact that, in distilling the ester, the boiling-point always rose a little above that for the pure ester.

The esterification experiments, wherein water was employed as a solvent for the sodium salt of the acid, were carried out as follows. The desired amount of sodium benzoate was dissolved in 150 to $200 \mathrm{cc}$. of water, all the benzyl chloride was added and the mixture was heated in an oilbath at IIO-II $5^{\circ}$. The flask was connected with a reflux condenser and carried an efficient stirrer. The reaction was allowed to proceed for 4 or 5 hours, although it seems certain that a shorter time would have sufficed. Then the ester was extracted with benzene, the solution was dried and fractionated. After the solvent was removed, the temperature rose rapidly and remained stationary for a short time in the neighborhood of the boiling-point of benzyl alcohol; then it rose again and remained at $3^{10-15^{\circ}}$ until practically all of the substance had distilled. Hardly any residue remained in the distilling flask. The ester was free from benzyl chloride, and one redistillation under reduced pressure, with hardly any loss of material, gave a product which was water-white, free from unpleasant or pungent odor, and gave no test for chlorine. Table II gives a summary of these results. It will be noticed that in Runs I to 6 the amount of sodium benzoate used was $50 \%$ in excess of that calculated; in Runs 7 and 8,200\% in excess; in. Run 9, the benzyl chloride was $200 \%$ in excess. The benzoic acid which remains unacted upon by the benzyl chloride is readily recovered from the aqueous solution.

\begin{tabular}{|c|c|c|c|c|c|c|}
\hline \multirow{3}{*}{$\begin{array}{l}\text { Run } \\
\text { No. }\end{array}$} & \multicolumn{4}{|c|}{$T_{A B L E}$ II. } & \multirow{2}{*}{\multicolumn{2}{|c|}{ Yield of ester. }} \\
\hline & \multirow{2}{*}{$\begin{array}{c}\text { Sodium } \\
\text { benzoate. } \\
\text { G. }\end{array}$} & \multirow{2}{*}{$\begin{array}{c}\text { Benzyl } \\
\text { chloride. } \\
\text { G. }\end{array}$} & \multirow{2}{*}{$\begin{array}{l}\text { Temperature } \\
\text { of oil-bath. } \\
\text { o C. }\end{array}$} & \multirow{2}{*}{$\begin{array}{l}\text { Benzoic acid } \\
\text { recovered. } \\
\text { G. }\end{array}$} & & \\
\hline & & & & & G. & $\%$ \\
\hline I... & 27 & 16.5 & $110-115$ & 13 & II & 40 \\
\hline $2 .$. & . 36 & $2 I$ & 100 & I7 & 22 & 63 \\
\hline $3^{a}$. & 55 & 32 & 50 & $4 \mathrm{I}$ & 3 & 6 \\
\hline $4 .$. & .. 55 & 32 & I I $5-120$ & 20 & 37 & 70 \\
\hline 5 . & . $\quad 55$ & 32 & I 15 & 21 & 37 & 70 \\
\hline $6 .$. & . 55 & 32 & II 5 & 22 & 37 & 70 \\
\hline $7 \ldots$ & . IIO & 32 & $1 \times 5$ & 70 & 42 & 79 \\
\hline $8 .$. & .220 & 64 & I I 8 & 143 & 84 & 79 \\
\hline $9 .$. & . . 29 & 75 & Iro & 14 & I7 & 40 \\
\hline
\end{tabular}

Benzyl Acetate.-Conrad and Hodgkinson ${ }^{1}$ gave explicit directions for the preparation of benzyl acetate. They advise heating anhydrous potassium acetate instead of sodium acetate with benzyl chloride in al-

${ }_{1}$ Courad and Hodgkinson, Ann, I93, 299 (1878). 
cohol as a solvent. Seelig ${ }^{1}$ substituted glacial acetic acid for alcohol and thereby was able to use sodium instead of potassium acetate with equally good results. Still, to convert $\mathrm{I}_{5} \mathrm{O} \mathrm{g}$. benzyl chloride required 200 cc. of acetic acid and 25 to 30 hours boiling. Bodroux ${ }^{2}$ reduced the time of reaction by employing lead instead of sodium acetate. He thus converted $8 \circ \mathrm{g}$. of benzyl chloride into the acetate in one hour with a yield of $60 \%$ of the pure product. Quite recently, Klever ${ }^{3}$ took out a patent, which suggested the tuse of glacial acetic acid and sodium acetate, but in much smaller proportion than Seelig used, namely, I.I to I.2 mol. of acid to I mol. of benzyl chloride.

We found that benzyl chloride and anhydrous sodium acetate, with copper as catalyst, and without the use of a solvent, gave from $30-40 \%$ ester after several hours of heating. But when the salt is dissolved in water and the mixture, thoroughly stirred, is heated as described for the benzoate, a yield of $80 \%$ of pure acetate, b. p. $205^{-2} 10^{\circ}$, is readily secured. The results are summarized in Table III. The amount of sodium acetate which is required for a run with $32 \mathrm{~g}$. of benzyl chloride is 20.5 $\mathrm{g}$. when an anhydrous salt is taken; the amount actually used is given in Col. 3 .

TABLE III.

32 G. of Benzyl Chloride Used in Each Experiment.

\begin{tabular}{|c|c|c|c|c|c|c|c|}
\hline \multirow{2}{*}{$\begin{array}{l}\text { Run } \\
\text { No. }\end{array}$} & \multirow{2}{*}{$\begin{array}{c}\text { Sodium } \\
\text { acetate. } \\
\text { G. }\end{array}$} & \multirow{2}{*}{$\begin{array}{c}\text { Excess } \\
\text { sait used. } \\
\text { G. }\end{array}$} & \multirow{2}{*}{$\begin{array}{c}\text { Temp. of } \\
\text { oil-bath. } \\
\circ \mathrm{C} .\end{array}$} & \multirow{2}{*}{$\begin{array}{l}\text { Time } \\
\text { of run. } \\
\text { Hrs. }\end{array}$} & \multirow{2}{*}{$\begin{array}{c}\text { Catalyst } \\
\text { or solvent. }\end{array}$} & \multicolumn{2}{|c|}{ Yield of estar. } \\
\hline & & & & & & G. & $\%$ \\
\hline I $\ldots \ldots$ & 36 & 16 & 200 & 6 & $\mathrm{Cu}$ & 13 & 34.6 \\
\hline $2 \ldots \ldots \ldots$ & 36 & $x 6$ & I $80-200$ & 5 & $\mathrm{HgCl}_{2}$ & $x_{4}$ & $37 \cdot 3$ \\
\hline $3 \ldots \ldots$ & 36 & 16 & 150 & 3 & $\mathrm{HgCl}_{2}$ & 19 & 50.6 \\
\hline $4 \ldots \ldots$ & 36 & I 6 & $I 40-I_{45}$ & 3 & $\mathrm{Cu}_{2} \mathrm{Cl}_{2}$ & o & o \\
\hline $5 \ldots \ldots$ & 30 & ro & I IO & $7 \cdot 5$ & $\mathrm{H}_{2} \mathrm{O}$ & 25 & 66.6 \\
\hline $6 \ldots \ldots$ & 53 & 33 & I I 5 & 8 & $\mathrm{H}_{2} \mathrm{O}$ & 30 & 80.0 \\
\hline $7 \ldots \ldots$ & 53 & 33 & II 5 & 8 & $\mathrm{H}_{2} \mathrm{O}$ & $3 I$ & 82.6 \\
\hline $8^{a} \ldots \ldots$ & . 105 & 85 & I 5 & 8 & $\mathrm{H}_{2} \mathrm{O}$ & 8 & $2 I .5$ \\
\hline
\end{tabular}

${ }^{a}$ Not enough water added to dissolve all of sodium acetate used.

Benzyl Propionate.-Conrad and Hodgkinson ${ }^{4}$ prepared this ester from potassium propionate and benzyl chloride in alcohol. The mixture was boiled from 30 to 40 hours. It can be prepared much more readily if an aqueous solution of the salt is used. Thus, $64 \mathrm{~g}$. of the acid was dissolved in about roo cc. of water, neutralized with sodium carbonate. $32 \mathrm{~g}$. of benzyl chloride was added, and the mixture was heated as described for the other acids. The ester possessed a most agreeable odor, and boiled at $220-230^{\circ}$. The yield was $85 \%$.

\footnotetext{
i Seelig, J. prakt. Chem., [2] 39, 164 (1889).

2 Bodroux, Bull. soc. chim., [3] 2I, 288 (I899).

${ }^{8}$ Klever, C. A., 9, 694 (ror5); Brit. pat. 20,504.

"Conrad and Hodgkinson, Ann., I93, 3 I I ( 1878 ).
} 
Benzyl Butyrate. ${ }^{1-}$ This ester also was prepared in aqueous solution, using $66 \mathrm{~g}$. of acid, neutralizing and adding $32 \mathrm{~g}$. of benzyl chloride, 37 g. of the ester was obtained, $i$. e., $83 \%$ yield. The ester boiled at $235^{-}$ $242^{\circ}$. The butyrate, similar to the acetate and propionate, possesses a pleasant aromatic odor.

Benzyl Lactate. - This ester was made similarly to the others. An aqueous solution of the sodium salt containing $67 \mathrm{~g}$. of lactic acid and $32 \mathrm{~g}$. benzyl chloride gave $25 \mathrm{~g}$., $55 \%$ yield, of ester which boiled between I 50 and $156^{\circ}$ under $205 \mathrm{~mm}$. pressure. It is practically devoid of odor.

Benzyl Phenyl Acetate.-This ester was first prepared by Slawick ${ }^{2}$ and later Hodgkinson ${ }^{3}$ made it by digesting benzyl chloride for a week with an alcoholic solution of phenyl acetate. By the method here described $49 \mathrm{~g}$. treated with $\mathrm{I} 2.6 \mathrm{~g}$. benzyl chloride gave $17 \mathrm{~g}$. of ester, b. p. $204-210^{\circ}$ under $20.5 \mathrm{~mm}$., which is a $75 \%$ yield. $23 \mathrm{~g}$. of phenylacetic acid out of the $26 \mathrm{~g}$. excess employed was recovered from the aqueous solution.

Benzyl Cinnamate.-Grimaux's ${ }^{4}$ procedure for the preparation of this ester in which sodium cinnamate is treated with benzyl chloride in alcohol, gave a yield of only $40 \%$ of a product contaminated with ethyl cinnamate. According to a procedure patented by Kalle and Co., ${ }^{5}$ solid sodium cinnamate heated with benzyl chloride at $140-170^{\circ}$ gives good yields of the ester. In our method, $40 \mathrm{~g}$. of the acid dissolved in Ioo cc. water was neutralized with sodium hydroxide and treated in the usual manner for 4 hours with I3 $g$. of benzyl chloride. At the end of the experiment $34 \mathrm{~g}$. of cinnamic acid was recovered, and $20 \mathrm{~g}$. of the pure ester, boiling between 240 and $244^{\circ}$ under $25 \mathrm{~mm}$. pressure, was obtained, which is $83 \%$ of the amount theoretically possible, calculated on the quantity of the benzyl chloride employed.

Benzyl Salicylate.-This ester, patented by the Aktien Gesellschaft ${ }^{6}$ for use as a fixateur in perfumery, was prepared by them by heating dry sodium salicylate with benzyl chloride at $130-140^{\circ}$; at higher temperatures, the phenolic hydroxyl group also reacts. We obtained the same ester by the use of aqueous solutions. Our yields varied from 40 to $45 \%$, the ester boiled between $2 \mathrm{II}$ and $214^{\circ}$ under $22.5 \mathrm{~mm}$. The use of acetyl salicylic acid instead of salicylic acid gave no better yield. In fact, the acetyl group was removed by hydrolysis during the process of esterification.

Dibenzyl Succinate.-This ester received considerable attention in

1 Conrad and Hodgkinson, Ann., 193, 3 I 7 (1878).

2 Slawick, Ber., 7, 1056 (1874).

${ }^{3}$ Hodgkinson, J. chim. Soc., 37, 485 (I880).

${ }^{4}$ Grimaux, Z. Chem, 5, 157 (1 869).

5 Friedlaender, 6, 1234; D. R. P. 127,649.

- Friedlaender, 6, I108; D. R. P. I 19,463. 
view of the possible existence of 2 isomeric esters corresponding to the 2 probable tautomeric modifications of the chloride of succinic anhydride. In the past this ester has been prepared by a variety of methods, from benzyl bromide and the silver salt of succinic acid; ${ }^{1}$ from benzyl alcohol and succinyl chloride at high temperatures, or from benzyl alcohol and succinic acid at $180^{\circ} .{ }^{2}$ from benzyl iodide and silver succinate. ${ }^{3}$ By all these methods the identical ester, m. p. $49^{-} 50^{\circ}$, was obtained. By our method, in aqueous solution, with an excess of sodium succinate and $25 \mathrm{~g}$. of benzyl chloride, boiled for 7 hours, we obtained $\mathrm{r} 3 \mathrm{~g}$. of dibenzyl ester, which is $43 \%$ of the theoretical amount. At the same time $9 \mathrm{~g}$. of benzyl alcohol was formed. The ester was distilled under highly reduced pressure. It melted without further purification at $47-48^{\circ}$.

Several other acids, with which only one or two runs were made, gave the following results. Oleic acid, about a $4.5 \%$ yield of ester, distilled under highly reduced pressure. Formic, oxalic and phthalic acids gave no ester

\section{Condensation with Phenols.}

The condensation of benzyl chloride with phenols has been the subject of numerous investigations. Iath and Grimaux, ${ }^{4}$ Sintenis, ${ }^{5}$ have shown for phenols, and Staedel, ${ }^{6}$ more fully, for phenol, $\alpha$ - and $\beta$-naphthols and for other phenols, that benzyl chloride and alkali salts of phenols when boiled in alcohol react and give the corresponding benzyl ethers of the phenols as expected. On the other hand, when benzyl chloride acts upon phenol, or upon $\alpha$-naphthol or $\beta$-naphthol in presence of small amounts of zinc dust, ${ }^{7}$ or in presence of zinc chloride, ${ }^{8}$ then the condensation occurs in a different sense, since benzyl phenols, $\mathrm{C}_{6} \mathrm{H}_{5} \mathrm{CH}_{2} \mathrm{C}_{6} \mathrm{H}_{4} \mathrm{OH}(p)$, or the corresponding benzyl naphthols, $\mathrm{C}_{6} \mathrm{H}_{5} \mathrm{CH}_{2} \mathrm{C}_{10} \mathrm{H}_{6}(\mathrm{OH})$ result.

We have performed some experiments in aqueous solution which bear upon the condensation of benzyl chloride with phenols; also some in the absence of solvents, and some with and without catalysts. As regards the experiments with alkaline solutions of phenols, one would have expected scarcely any other result than the formation of benzyl alcohol, if the weak acid character of the phenols and the consequent hydrolysis of their salts is taken into consideration. This, however, is far from being the case. In each experiment, the $32 \mathrm{~g}$. of benzyl chloride used, required, theoretically, $23 \mathrm{~g}$. of phenol or $38 \mathrm{~g}$. of naphthol, respectively, while the alkali employed was exactly equivalent to the amount of phenol. Other-

${ }^{1}$ Del Zanna and Guareschi, Gazz. chim. ital., rI, 256 (I88r).

2. C. A. Bischoff and A. von Hedenström, Ber., 35, 4078 (rgoz).

${ }^{3}$ R. Meyer and K. Marx, ibid., 4I, 2460 (Igo8).

4 Latth and Grimaux, Ann., I43, 8I (I867).

'Sintenis, ibid., I6I, 337 (I872).

'Staedel, ibid., 217, 43 (1883).

7 H. Schiff, Ber., 5, 288, 435 (I872).

${ }^{8}$ Ad. Liebmann, ibid., 15, 152 (1882). 
wise, the procedure was similar to that employed in the esterification experiment. The phenol, whenever it was possible, was separated by means of water, otherwise a mixture of the phenol and benzyl phenol was separated from benzyl ether by means of alkali, in which the benzyl ethers are insoluble. The final separation and purification was accomplished by, distillation under reduced pressure and by subsequent crystallization of solid products. The results are summarized in Table IV.

TABLE IV.

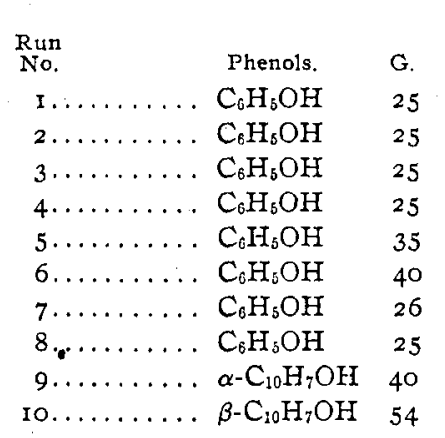

\begin{tabular}{|c|c|}
\hline $\begin{array}{c}\text { Temperature } \\
\text { of oil-bath. } \\
0^{\circ} \mathrm{C} \text {. }\end{array}$ & $\begin{array}{l}\text { Time } \\
\text { of run. } \\
\text { Hrs. }\end{array}$ \\
\hline $100-10_{5}$ & 3 \\
\hline I $50-$ I 80 & 3 \\
\hline I I5-I 20 & 3 \\
\hline I $40-I 45$ & 3 \\
\hline IO5 & I \\
\hline I IO & 2 \\
\hline $120-125$ & 8 \\
\hline 230 & 5 \\
\hline 105 & 2 \\
\hline IIO & 2 \\
\hline
\end{tabular}

\begin{tabular}{|c|}
\hline $\begin{array}{c}\text { Catalyst } \\
\text { or } \\
\text { solvent. }\end{array}$ \\
\hline$\cdots$ \\
\hline$\cdots$ \\
\hline $\mathrm{Cu}$ \\
\hline $\mathrm{Cu}$ \\
\hline $\mathrm{H}_{2} \mathrm{O}$ \\
\hline $\mathrm{H}_{2} \mathrm{O}$ \\
\hline Acetone \\
\hline Toluene \\
\hline $\mathrm{H}_{2} \mathrm{O}$ \\
\hline $\mathrm{H}_{2} \mathrm{O}$ \\
\hline
\end{tabular}

$\begin{array}{cc}\text { Ethers, } & \text { Yield of, } \\ \begin{array}{c}\text { Benzyl- } \\ \text { phenols, } \%\end{array} \\ \ldots & 24 \\ \ldots & 30 \\ \ldots & 40 \\ \ldots & 35 \\ 60 & \ldots \\ 6 \mathrm{r} & \ldots \\ \ldots & \ldots \\ \ldots & 13 \\ 8.5 & 20 \\ 5 & 50\end{array}$

So far as they go, these results indicate, (I) that in the absence of solvents

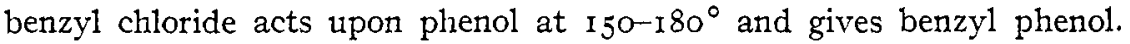
In presence of copper, the yields are much better and the reaction temperature need not exceed II $-120^{\circ}$; with zinc as a catalyst, even room temperature suffices; ${ }^{1}(2)$ that in aqueous solution quite satisfactory yields of benzyl-phenyl ether are obtained, almost as good as those with alcohol as a solvent, or as those secured by the electrolytic reduction of phenyl benzoate; (3) that the naphthols in aqueous solution also give some of the corresponding ethers, but a great portion is converted into the corresponding benzyl naphthols-a behavior wholly unanticipated. If these results can be verified by further experiments it would seem that $\beta$-naphthol is considerably more reactive toward benzyl chloride than $\alpha$-naphthol is. This unanticipated behavior of the naphthols is somewhat akin to the behavior of phenols toward carbon tetrachloride and chloroform in presence of concentrated alkalies, the Reimer-Tiemann reaction.

\section{Benzyl Chloride and Amines.}

Leaving entirely out of consideration the many various indirect methods which lead to the formation of either the mono-, the di-, or the tri-benzylamines exclusively, we have the method, usual in reactions of this nature, which consists in heating alcoholic ammonia and benzyl chloride in a

1 Marussia and Bakunin, Gazz, chim. ital., [2] 33, 454 (1903).

${ }^{2}$ C. Mettler, Ber., 38, I752 (I905). 
sealed tube. ${ }^{1}$ Under these circumstances a mixture of the 3 amines results. The tertiary amine constitutes by far the greatest portion of the reaction products. Mason ${ }^{2}$ showed that benzyl chloride is attacked by a cold alcoholic solution of ammonia. He employed a $15 \%$ alcoholic ammonia solution. When he allowed a large excess of ammonia, $20 \mathrm{~mol}$. to I mol. of benzyl chloride, to stand for 5 days and subsequently heated it for a short time, he obtained a combined yield of the 3 amines equal to $75 \%$, distributed thus, $29 \%$ to the mono-, $38 \%$ to the di-, and $8 \%$ to the tribenzylamine. With $2 \mathrm{~mol}$. of ammonia to I mol. benzyl chloride, under the same conditions, practically all of the latter was converted into tribenzylamine. Trials with an aqueous solution of ammonium hydroxide gave us indications of favorable reaction, and the substitution of ammonium carbonate for ammonia gave results which leave no doubt of the advantages of this procedure. When only $5 \mathrm{~mol}$. of ammonium carbonate and I mol. of benzyl chloride were heated for 5 to 6 hours, a combined yield of $80 \%$ of the amines was obtained, distributed thus, 16\% to pure mono-, $20 \%$ to di-, and $44 \%$ to tribenzylamine. The separation was made according to Mason's method, by fractional distillation under reduced pressure and by crystallization of the tribenzylamine from alcohol. It seems quite probably, that, with a larger excess of ammonium carbonate, with lower temperature and longer time, the relative proportion of the primary amine may become larger.

In the preparation of benzyl derivatives of aniline and its homologues in aqueous solution, we had better results than in the case of benzylamine, and, by varying the relative proportion of aniline and benzyl chloride, we could get either mono- or dibenzyl aniline, respectively, as the principal product of the reaction. In the past it has been the custom to use the anhydrous ingredients, often with the addition of solid alkalies and to heat these under pressure, or for a longer period in open flasks at lower temperatures.

Except for the patented method of making dibenzyl-m-toluidine, ${ }^{3}$ we are not aware that, prior to this, aqueous solutions of the aromatic amines have been employed for the preparation or benzyl anilines. In Table $\mathrm{V}$ is given a summary of the results we obtained. Theoretically, I mol. of benzyl chloride requires either 2 mols. of the amine or I mol. of the amine plus $1 / 2$ mol. of sodium carbonate; accordingly, the theoretical amounts for $32 \mathrm{~g}$. of benzyl chloride are $28 \mathrm{~g}$. of the hydrated ammonium carbonate, $22 \mathrm{~g}$. of aniline and $28 \mathrm{~g}$. of methyl aniline or toluidine, plus I3 g. of sodium carbonate.

\footnotetext{
${ }_{1}$ H. Limpricht, Ann., I44, 305 (1867).

2 Mason, J. Chem. Soc., 63, I312 (1893).

${ }^{3}$ Friedlaender, 6, 256; D. R. P. I 5,653 .
} 
TABLE V.

\begin{tabular}{|c|c|c|c|c|c|c|c|}
\hline \multirow[b]{2}{*}{$\begin{array}{c}\left.\mathrm{Ir}_{4}\right)_{2} \mathrm{CO}_{3} \mathrm{H}_{2} \mathrm{O} \\
\text { at mine. }\end{array}$} & \multirow[b]{2}{*}{ G } & \multirow[b]{2}{*}{$\begin{array}{c}\text { Benzyl } \\
\text { chlor:de. } \\
G \text {. }\end{array}$} & \multirow{2}{*}{$\begin{array}{l}\text { Temperature } \\
\text { of oil-bath. } \\
\text { of. }\end{array}$} & \multirow{2}{*}{$\begin{array}{c}\text { Time } \\
\text { of run. } \\
\text { Hrs. }\end{array}$} & \multicolumn{3}{|c|}{ Yield of amine } \\
\hline & & & & & $\begin{array}{c}\text { Monoben- } \\
\text { zyl, \%. }\end{array}$ & $\begin{array}{l}\text { Diben- } \\
\text { zyl } \% \text {. }\end{array}$ & $\begin{array}{l}\text { Triben- } \\
\text { zyl, \%. }\end{array}$ \\
\hline $\left.\mathrm{NH}_{4}\right) \mathrm{Cr} \mathrm{H}_{2} \mathrm{O} \ldots$ & 28 & 32 & IIO & $5 \cdot 5$ & 9 & 9 & 62 \\
\hline $\left.\mathrm{H}_{4}\right) \mathrm{CO}, \mathrm{IIO} \mathrm{O}$ & 71 & 32 & $80-85$ & 5 & $x 9$ & 18 & 50 \\
\hline $\mathrm{NH}_{4} / 2 \mathrm{CO}_{3} \mathrm{IH}_{2}()$. & 213 & 96 & $85-90$ & 6 & 16 & 20 & 44 \\
\hline$H . N I H, \ldots \ldots \ldots$ & 2.3 & .32 & $9.5-100$ & 4 & 56 & $2 I$ & . \\
\hline${ }_{6} \mathrm{H}_{6} \mathrm{NH}_{2} \ldots \ldots$ & $\therefore$ & 14 & $95-100$ & 4 & 13 & 60 & . \\
\hline${ }_{6} \mathrm{H}_{6} \mathrm{NH}, \mathrm{CH}_{3} \ldots$ & 27 & 32 & $9.5-100$ & 4 & 90 & . & .. \\
\hline$-\mathrm{CH}_{3}, \mathrm{C}_{6} \mathrm{H}_{4} \mathrm{NH}_{2 .}$ & $2 \mathrm{I} .5$ & 50 & $95-100$ & 4 & . & 76.6 & .. \\
\hline $2-\mathrm{CH}_{3}, \mathrm{C}_{6} \mathrm{H}_{4} \mathrm{NH}_{2}$. & 21.5 & 50 & $95-100$ & 4 & . & $7 \mathrm{I} .4$ & .. \\
\hline
\end{tabular}

\section{Benzyl Chloride and Sodium Cyanide.}

From the time of Cannizzaro' it has been customary to use alcohol in carrying out the reaction between benzyl chloride or any of its analogues and sodium or potassium cyanide, for fear that if water be used, hydrolysis of the chloride would occur. The fear is not ungrounded, but, we think it is exaggerated. In some cases it has been observed ${ }^{2}$ that the addition to the alcohol of a certain amount of water is desirable, not merely in order to induce greater solubility of the sodium salt, but for the reason that, otherwise, the reaction is likely to proceed in a different sense. For the preparation of benzyl cyanide, itself, Meyer and Jacobson's ${ }^{3}$ direct that 2 parts of alcohol and I part of water be used. Unfortunately, the yield of the cyanide obtainable under such conditions has not been indicated. In our experiment with aqueous solutions of sodium cyanide we obtained yields of benzyl cyanide equal to 50 and $60 \%$. In the experiments given in Table VI, we used. $32 \mathrm{~g}$. of benzyl chloride in each case, which required, theoretically, i $2 \mathrm{~g}$. of sodium cyanide; the salt was

TABLE VI.

32 G. of Benzyl Chloride Used in Each Experiment.

\begin{tabular}{|c|c|c|c|c|}
\hline \multirow{2}{*}{$\begin{array}{cc}\text { Run } & \text { cyanid } \\
\text { No. } & G \text {. }\end{array}$} & \multirow{2}{*}{$\begin{array}{l}\text { Temperature } \\
\text { of oil-bath. } \\
\text { o. C. }\end{array}$} & \multirow{2}{*}{$\begin{array}{l}\text { Time } \\
\text { of run. } \\
\text { Hrs. }\end{array}$} & \multicolumn{2}{|c|}{ Yield of cyanide. } \\
\hline & & & G. & $\%$. \\
\hline $1 \ldots \ldots \ldots \ldots \ldots \ldots \ldots$ & $70-75$ & 3 & 5 & I 7 \\
\hline $2 \ldots \ldots \ldots \ldots \ldots \ldots 36$ & $110-115$ & 4 & II & 40 \\
\hline $3 \ldots \ldots \ldots \ldots \ldots \ldots \ldots$ & 105 & 2 & I $5 \cdot 5$ & 53 \\
\hline $4 \ldots \ldots \ldots \ldots \ldots \ldots \ldots$ & $110-$ I I 5 & 1.5 & I5 & 51 \\
\hline $5 \ldots \ldots \ldots \ldots \ldots \ldots 24$ & 105 & $\mathbf{I}$ & 10.5 & 36.2 \\
\hline $6 \ldots \ldots \ldots \ldots \ldots \ldots 24$ & 105 & I & 20 & 70 \\
\hline $7 \ldots \ldots \ldots \ldots \ldots \ldots$ I6 & I IO-I I5 & 2.5 & $15 \cdot 5$ & 53 \\
\hline $8 \ldots \ldots \ldots \ldots \ldots \ldots$ & IOS & $\mathbf{r}$ & 19.5 & 67 \\
\hline $9 \ldots \ldots \ldots \ldots \ldots \ldots$ & I05 & $\mathbf{I}$ & $17 \cdot 5$ & 60 \\
\hline $10 \ldots \ldots \ldots \ldots \ldots \ldots$ I6 & $102-105$ & $\mathbf{I}$ & 18 & 63 \\
\hline$I x \ldots \ldots \ldots \ldots \ldots \ldots \ldots$ & 105 & $\mathbf{I}$ & $13 \cdot 5$ & 46.5 \\
\hline $12 \ldots \ldots \ldots \ldots \ldots \ldots \ldots$ & 105 & I & 15 & $5 I$ \\
\hline
\end{tabular}


dissolved in $100 \mathrm{cc}$. of water. It will be noticed that too great an excess of sodium cyanide seems to be detrimental rather than beneficial; presumably it induces hydrolysis of the benzyl cyanide to phenyl-acetic acid as well as some benzyl alcohol. For the same reasons, prolonged boiling should be avoided. The results are summarized in Table VI. In the first 4 runs, the benzyl chloride was added all at one time; in the remaining runs, it was added from a dropping funnel during the course of $1 / 2$ to $3 / 4$ hour. The reaction seems to be extremely sensitive to the influence of various factors, and the yields of the cyanide vary in different experiments, notwithstanding the fact that these experiments have been carried out under as nearly identical conditions as possible.

\section{Benzyl Alcohol.}

Cannizzaro, ${ }^{1}$ in 1853 , showed that benzaldehyde under the influence of a strong solution of potash, suffers auto-oxidation and that half is converted into acid and half into alcohol. This reaction still continues to serve as one of the standard methods for the preparation of benzyl alcohol. R. Meyer ${ }^{2}$ substituted water for alcohol as a solvent and Missenheimer ${ }^{3}$ improved the procedure of purification. In the development of the methods for obtaining the alcohol from benzyl chloride, two lines have been followed, first, the direct hydrolysis of the chloride; second, previous conversion of the chloride into an ester, usually the acetate, with subsequent hydrolysis of the latter. For obtaining it by the indirect method, Cannizzaro 4 used alcoholic potash for saponification of the acetate. Seelig ${ }^{j}$ used the same substance but only I mol; ; and, recently, Klever $^{6}$ patented a process of hydrolyzing the ester by means of water containing sodium acetate or sodium carbonate. In this connection, Mettler's ${ }^{7}$ indirect method, one possibly of wide application, may also be mentioned. It consists in the electrolytic reduction of the esters of benzoic acid to benzyl alcohol.

The hydrolysis of benzyl chloride directly to the alcohol has also received considerable attention. Lauth and Grimaux ${ }^{8}$ boiled the chloride for a short time with water containing freshly precipitated lead oxide; Niederist ${ }^{9}$ boiled it with water alone for a long period; Meunier ${ }^{10}$ used one

1 Cannizzaro, Ann., 88, 129 (I853).

${ }^{2}$ R. Meyer, Ber., 14, 2390 (1881); see also Kohn and Tranton, J. Chem. Soc., 75, I 55 (1899).

${ }^{3}$ Missenheimer, Ber., 4I, 1420 (I go8).

4 Cannizzaro, Ann., 96, 246 (1855).

S Seelig, J. prakt. Chem., [2] 39, I66 (1889).

- C. A., 9, 694 (1915); Brit. Pat. 20,504.

7 Friedlaender, 8, 144; D. R. P. 166,181.

${ }^{8}$ Lauth and Grimaux, $A$ nn., I43, 81 (1867).

- Niederist, ibid., 196, 353 (1879).

${ }^{10}$ Meunier, Bull. soc. chim., 38, 159 (1882). 
mol. of potassium carbonate in Io parts of water; and, lately, Klever ${ }^{2}$ patented a procedure wherein benzyl chloride is heated in the presence of an excess of water, intimately mixed with magnesium hydroxide, or hydroxides of alkaline earths, or other basic hydroxides; also, by heating the chloride with water and alkaline carbonates. ${ }^{2}$ Although the ground appeared to be fairly well covered, it seemed not without interest to make a few trials to obtain benzyl alcohol directly from the chloride according to our procedure, and to determine, if possible, under what conditions of hydrolysis the most favorable yields of the alcohol may be expected. The results are summarized in Table VII.

TABLE VII.

32 G. of Benzyl Chloride Used in Each Experiment.

\begin{tabular}{|c|c|c|c|c|c|c|}
\hline \multirow[b]{2}{*}{$\begin{array}{l}\text { Run } \\
\text { No. }\end{array}$} & \multirow[b]{2}{*}{ Alkali. } & \multirow[b]{2}{*}{ G. } & \multirow{2}{*}{$\begin{array}{l}\text { Temperature } \\
\text { of oil-bath. } \\
\text { o. C. }\end{array}$} & \multirow{2}{*}{$\begin{array}{c}\text { Time } \\
\text { of ruIn. } \\
\text { Frss. }\end{array}$} & \multicolumn{2}{|c|}{ Yield of alcohol. } \\
\hline & & & & & G. & $\%$ \\
\hline $1 .$. & $\mathrm{Na}_{2} \mathrm{~B}_{4} \mathrm{O}_{7} \cdot 10 \mathrm{H}_{2} \mathrm{O}$ & 144 & IIO-I I 5 & 8 & 4 & 15 \\
\hline $2 .$. & $\mathrm{Na}_{2} \mathrm{CO}_{8}$ & 40 & I1O-II5 & 10 & 18 & 66 \\
\hline $3 .$. & $\mathrm{Na}_{2} \mathrm{CO}_{8}$ & 40 & IIO-II5 & 6 & $2 I$ & 78 \\
\hline $4 .$. & $\mathrm{Na}_{2} \mathrm{CO}_{3}$ & 26 & $110-115$ & 4 & 20.5 & 76 \\
\hline $5 \cdots$ & $\mathrm{Na}_{2} \mathrm{CO}_{3}$ & 26 & I 10-I I 5 & 2.5 & 22 & $81 \cdot 5$ \\
\hline 6. & $\mathrm{Na}_{2} \mathrm{CO}_{3}$ & 13 & $110-115$ & 2 & 22 & $8 \pi \cdot 5$ \\
\hline o.. & $\mathrm{NaOH}$ & ro & & & & \\
\hline $7 .$. & $\mathrm{NaOH}$ & 20 & I $20-125$ & I & 21.5 & 80 \\
\hline
\end{tabular}

Obviously, the data at hand are not sufficient to warrant drawing very definite conclusions. Nevertheless the results indicate $(a)$ that the shorter the period of boiling during hydrolysis, the better the yield of the alcohol, presumably because there is likely to be less oxidation of the alcohol to aldehyde and acid; (b) that it is preferable to employ sodium hydroxide rather than the carbonate, as the hydrolysis will thus be completed in a briefer period.

\section{Summary.}

(1) It has been shown that benzyl chloride, heated with the dry salts of various organic acids in the presence of copper as a catalyst, gives fair yields of the corresponding esters. Some benzyl chloride is lost through decomposition under the influence of the catalyst.

(2) The same benzyl esters may be obtained in purer state and in better yields, up to $85 \%$, when benzyl chloride and aqueous solutions of the salts of the corresponding acids are heated and thoroughly stirred at the same time.

(3) Benzyl chloride condenses with sodium phenolates in aqueous solution and gives fair yields of mixtures of benzyl ethers "and benzyl phenols; the formation of the latter under these circumstances is surprizing.

(4) Benzyl chloride gives good yields of mono-, di-, and tribenzyl amines

1 Klever, C. A., 8, 2781 (1914); Fr. Pat. $462,438$.

${ }^{2}$ C. A., 9, 694 (1915); Brit. Pat. 20, 504 . 
when heated with aqueous solutions of ammonium carbonate; good yields of the corresponding benzyl anilines when treated, similarly, with aniline, methyl aniline, toluidine, etc.

(5) Benzyl cyanide is obtainable in 50 to $60 \%$ yields from benzyl chloride and sodium cyanide in aqueous instead of alcoholic solution.

(6) It has been shown what conditions of procedure are likely to prove most serviceable in the hydrolysis of benzyl chloride to benzyl alcohol.

ANn Arbor, Mrchighis.

[Contribution from the Department of Chemistry, Yale UniverstTy.]

\title{
THE INTERACTION OF CARBON DISULFIDE WITH AMMONIUM CARBONATE.
}

\author{
BY FrancoIs A. GILFIIIAN.
}

Received July 2, 1920.

The work described in this paper represents one phase of an extensive investigation now in progress in the Sheffield Laboratory, dealing with the chemistry of carbon disulfide, and was undertaken by the writer at the suggestion of Professor Treat B. Johnson. ${ }^{1}$

In the development of the researches on pyrimidines and hydantoins which have been conducted in the above laboratory for several years, a wide use has been made of thio-urea for the synthesis of a great number of new combinations in these 2 cyclic series of organic compounds. The reagent has been used in large quantities for this work, and the largest proportion of it has been prepared by co-workers in the laboratory by molecular rearrangement of ammonium thiocyanate. The yield so obtained is not satisfactory, the best result that one can expect to obtain being about $25 \% .^{2}$ Evidence has been obtained, however, which indicates that the velocity constant of the reversion of these 2 isomers is a varible factor, and that the equilibrium percentage of thio-urea is influenced, not only by the presence of other salts, but is also concerned with other important experimental factors or conditions which are not well understood. ${ }^{3}$

Inghilleri" has recently described in a paper entitled, "A New Process for the Preparation of Ammonium Sulphocyanate and Thio-urea," a method for synthesizing thio-urea, which gives, according to him, prac-

I In our future work, we will take up the study of high temperature reactions with carbon disulfide, the influence of catalysts on well known reactions of this reagent which proceed with slow velocity, and also an investigation of photochemical influences at low and high temperatures. (T. B. J.)

2'Reynolds and Werner, J. Chem. Soc., 83, I (1903).

${ }^{3}$ Atkins and Werner, ibid., IoI, 1982 (r912); Johnson, Hill and Bailey, This Journal, 37, 2406 (rg15); Claus, Ann., I79, r28 (1875); Waddell, J. Phys. Chem., 2, 525 (I 898 ).

${ }^{4}$ Inghilleri, Gazz. chim. ital., 39, 634 (I909). 